\title{
COMPONENTS OF THE FINANCIAL PERFORMANCE OF AGRICULTURAL ENTERPRISES
}

\author{
M. Beranová, M. Basovníková
}

Received: August 31, 2011

\begin{abstract}
BERANOVÁ, M., BASOVNÍKOVÁ, M.: Components of the financial performance of agricultural enterprises. Acta univ. agric. et silvic. Mendel. Brun., 2011, LIX, No. 7, pp. 57-68

Financial performance of agricultural enterprises is discussed mainly in relation to agricultural subsidies policy of the Government. Agriculture is undoubtedly a specific sector of the national economy because the market conditions do not ensure a settlement of production costs of agricultural commodities. Than the most of agricultural enterprises have negative financial performance measured with the Economic Value Added (EVA).

The aim of this paper is to identify and determine the main factors influencing the value of the EVA indicator in agricultural enterprises while the analysis is focused especially on four variables directly entering the calculation of economic value added. But the fact that these four variables are functions of other variables has to be also taken into account. Constructed multi-dimensional regression model corresponds with the fundamental logic of the calculation of economic value added. It has been observed that the strongest influence on the value of EVA stands on the side of operating profit. But in agricultural enterprises, the important part of this profit consists just in the agricultural production subsidies. This way, these subsidies become the substantial part of the performance of agricultural enterprises.
\end{abstract}

agricultural enterprises, cost of capital, debts, economic value added, equity, financial performance, operating profit

Currently, financial performance of agricultural enterprises belongs to the group of problems which are inflected quite often. Objectively, the main reason for these discussions is the agricultural subsidies policy. The fact is that from the financial performance point of view, agriculture is a specific sector of national economy. As Seják (2011) has stated: The market, as the main tool of exchange, is not able to ensure a 'normal' settlement of production costs to the farmers. ${ }^{1}$ Resources which are the inputs of agricultural production are consumed at a minimal level of effectiveness, and substantial share of agricultural enterprises shows the losses that would be even deeper if there are no subsidies for agricultural production. Then, very low financial performance of agricultural business entities is obvious. An integral part of the agricultural sector that also substantially creates the financial performance of agricultural enterprises, are the environmental aspects as well as the externalities produced by agriculture. Economic reform and subsequent transformation of the Czech economy at the beginning of the 90's of the $20^{\text {th }}$ century have brought a strong pressure on conformity of agriculture to the new economic conditions. Higher prices of inputs in connection with the lower prices

1 Quotation according to Seják et al. (2011), Globalizace a udržitelnost českého zemědělství (Globalization and Sustainability of the Czech Agriculture). On-line available from: http://fzp.ujep.cz/projekty/1J-055-05-DP1/Glob_ URCSZ07_EK_AKI.ppt. 
of agricultural production have led to serious slump in profits of agricultural enterprises. This situation was lasting until 2001 when some stabilization steps have been realized in the agricultural sector. Nevertheless, improvement in the results of agricultural enterprises was recorded as long as 2004 that is the year of entrance of the Czech Republic to the European Union. This has meant the increase in agricultural subsidies, and these subsidies remain as an element maintaining the economic results of agricultural enterprises above a limit of loss. This way, the financial performance of agricultural enterprises is still on the very low level.

\section{METHODS AND RESOURCES}

Approach to the performance of company can be taken from various angles and different subjects operate with different meaning of the term. Then there are various methods how to measure and evaluate the performance as well. But the main question is how to make this measurement objective (Kislingerová, 2009). Generally, performance is seen as some ability of a subject to reach some defined results which are comparable with results of other subjects. A range of performance measures is more of less marketing oriented, e.g. market growth, market share, increase in sales, rate of customers' maintenance etc. It is obvious that these criteria are irrelevant in many industries. One of these sectors is also agriculture.

Objective of this paper is to identify the key components of performance of agricultural enterprises where the term "performance of an enterprise" is defined as financial performance measured with the indicator of economic value added (EVA). In order to fulfil the objective, the primary quantitative research has been realized while two statistical sets of agricultural enterprises are used. The first statistical set consists of 50 agricultural enterprises from the Region of Zlín, the second set is consisting of 50 agricultural enterprises farming in the South Moravia Region. In both, there are the enterprises doing their business as legal persons, i.e. joint-stock companies, limited companies and cooperatives, which are of a different size. For the purpose of identification of substantial influences on the value of EVA indicator, 13 statistical characteristics have been observed on these two sets. These characteristics are those entering the calculation of economic value added directly as well as indirectly. These variables are especially:

- Net operating profit after taxation (NOPAT).

- Amount of equity.

- Amount of debts.

- Cost of equity.

- Cost of debts.

- Weighted average cost of capital (WACC).

- Total indebtedness of company.

- Time interest earned ratio.
- Current ratio.

- Return on equity.

- Return on assets.

- Scoring.

Besides these variables another variable has been observed as well. This variable is of course the economic value added which is subsequently defined as dependent variable within the regression analyses.

In order to define the significant components creating the economic value added, the analyses of interaction between variables have been applied, especially the correlation analysis and regression analysis. Analysis of variance (ANOVA) has been used as well to identify the statistically significant differences between the two statistical sets.

\section{Measurement of the financial performance of companies}

Performance of a business entity is often spoken in connection with productivity which is determined by two parameters. These are as follows:

- Percentage of a resource utilization.

- Production speed of a resource (Skorkovský, 2005).

Nevertheless, productivity of resources is influenced with other related resources. It is rather obvious that in such a point of view, agriculture is a specific sector again. For example, in the context of the second parameter mentioned, it is objectively not possible to increase the production speed of a resource in order to increase productivity. From the viewpoint of managers, increasing the productivity is connected with decrease in costs of a production unit. But this aspect is without any doubt neither, not only within the agricultural production but possibly in connection to any production activity.

In the past, one of the very popular performance measures has been the indicator of Return on Equity (ROE). As a basis of comparison, this measure has lost its information value with a gradual employment of debts within the capital structure as an important resource of funding the business activities. One of new approaches that has been created in order to objectivise a measurement of financial performance of companies is the Economic Value Added (EVA).

The indicator of economic value added has been constructed in the USA at the early 90 's of the $20^{\text {th }}$ century by the consulting company Stern Stewart \& Co. Firstly, it has been supposed as a tool of management and valuation of business entity. Stewart (1991) by himself has defined the economic value added as operational profit after deduction of cost of capital employed in order to make this profit. This way it goes about the concept of residual income that the company has to make in order to reach such a productivity of capital which is even higher than these costs of capital, i.e. in order to create some added value which would increase the value for owners (Hamilton, Rahman \& Lee, 2009). Regarding to the fact that this indicator has been 
constructed in the United States, its application in the Czech Republic faces especially to the problems arising from actual domestic accounting standards that often prefer a form over the economic substance. That is why it is not possible to take the figures reported in financial statements automatically into the calculation of economic value added, e.g. capital and operating profit have to be adjusted (Beranová, Basovníková \& Martinovičová, 2010).

Various approaches are used for calculation of the economic value added while the most known is the original approach presented as EVA Entity which is base on the formula

$$
E V A=N O P A T-C \times W A C C
$$

or also

$$
E V A=N O P A T-N O A \times W A C C,
$$

where:

NOPAT.... is the Net Operating Profit after Taxation, C............... is capital employed in the ordinary operating activities,

NOA .........are Net Operating Assets which are an equivalent of capital, i.e. the assets employed in the ordinary operating activities,

WACC ..... is Weighted Average Cost of Capital consisting of all the capital employed in the operating activities, i.e. both equity and capital of creditors (Neumaierová \& Neumaier, 2002).
In the second approach, the economic value added is presented as EVA Equity. This is also the alternative calculation of this indicator according to the methodology of the Ministry of Industry and Trade of the Czech Republic. In this approach, there is no request of transformation of standard financial statements into the 'economic' ones. The authors have used this approach for the purposes of this article at measuring the economic value added in the observed statistical units of the two sets.

Mař́k \& Maříková (2005) then add the third method of economic value added calculation, EVA APV which works with the value of enterprise as a sum of two elements, i.e. a sum of value of enterprise at zero indebtedness and the present value of tax saving. Then the value of debts bearing interest are deducted, eventually the value of nonoperating assets is deducted as well.

One of the possible decompositions of the economic value added is its presentation in three basic areas which are as follows:

- Operating activities which are represented by the net operating profit after taxation (NOPAT), i.e. the difference between operational revenues and operational costs, income tax included.

- Financing activities represented by the weighted average cost of capital (WACC) that reflects the capital structure of a company as well as the risks of a company.

- Investment activities given by the value of the capital invested, i.e. not only fixed assets but the working capital as well (Remeš, 2009).

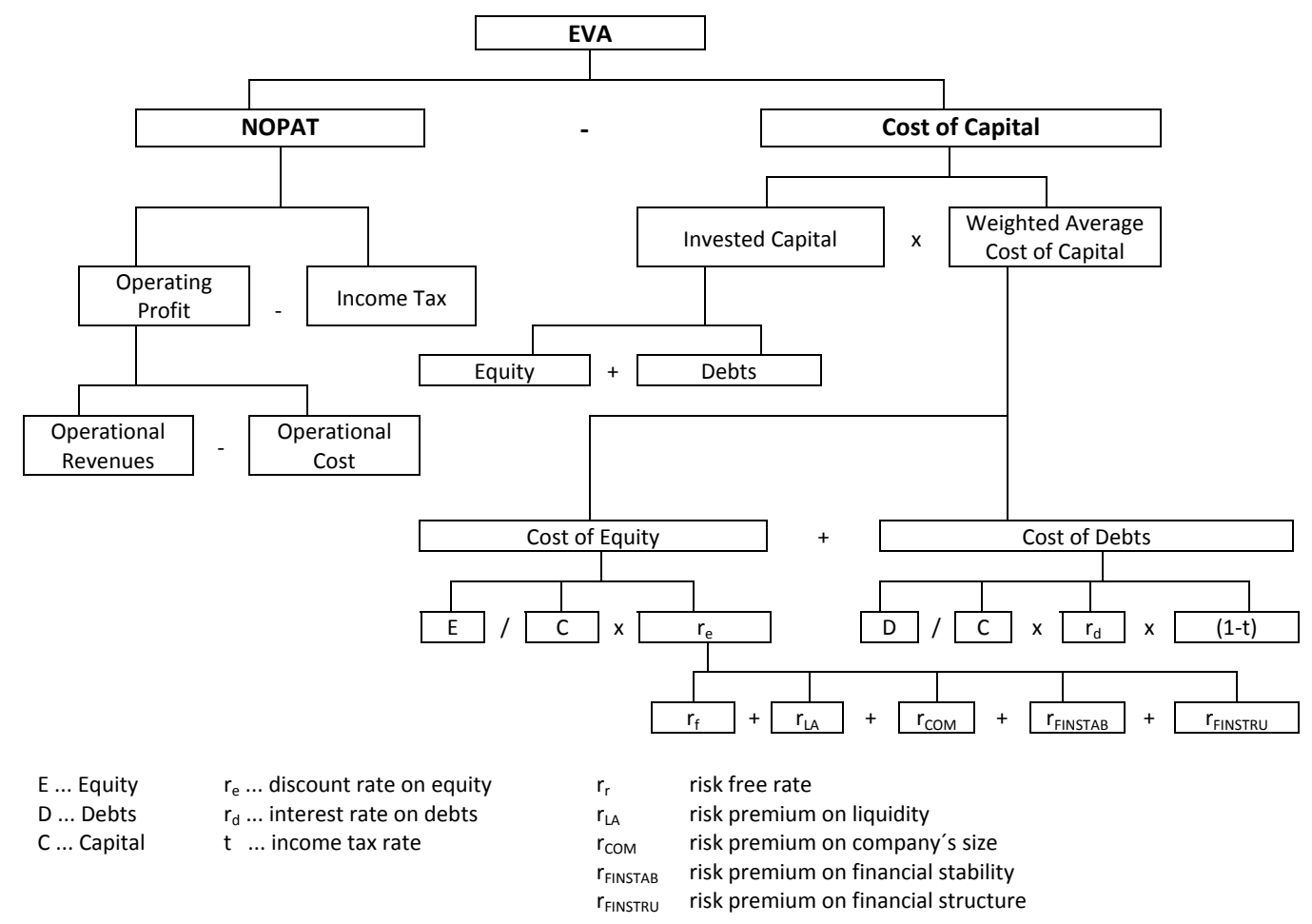

1: Decomposition of Economic Value Added 
These three areas are possible to find on the Fig. 1 that is also the reasoning of selection of statistical characteristics observed in the agricultural enterprises from the viewpoint of their influence on the value of the EVA indicator.

\section{Financial performance of agricultural enterprises}

Financial performance of the agricultural enterprises is objectively influenced with a range of non-financial factors which are not possible to be managed from the side of a business entity. Typical example of such influence is the weather but financial performance of an agricultural enterprise is influenced with the natural conditions in general. For this reason the two statistical sets of agricultural enterprises have been created and are consisting of agricultural enterprises farming under different natural conditions in different regions of the Czech Republic. These different natural conditions lead to different agricultural commodities produced there.

In the Region of Zlín, positive values of the EVA have been observed only in 20 per cent of enterprises. The mean of variable is also negative $-4.540,80$ thousand CZK with the standard deviation of 10.665,60 thousand CZK. In comparison with the South Moravia Region, the results there are not substantially different. Positive economic value added has been observed in 9 companies, i.e. in 18 per cent of statistical units. In the statistical set of the South Moravian agricultural enterprises, the mean of economic value added is $-5.108,46$ thousand CZK with the standard deviation of 20.871,33 thousand CZK. But in this statistical set, the mean is strongly overestimated with the outlayer, extremely high value of EVA. 10 percent trimmed mean than has the value of $-6.066,05$ thousand CZK. Analysis of variance (ANOVA) realized on the significance level of $\alpha=0.05$ has proved that significant statistical difference between these two sets does not exist, respectively that the values of EVA observed in these two statistical sets are originated in the same population and this way, they are not influenced by different factors. This result can theoretically reject the submitted premise about the influence of different natural conditions in the chosen regions.

As the one whole these two statistical sets are characterized by the mean of $-4.829,10$ thousand CZK with the standard deviation of 16.627,01 thousand CZK. Value of the 10 percent trimmed mean is $-5.114,53$ thousand CZK, and it proves the overestimation of the mean by extremely high value of outlayer. Generally, the economic value added is rather low here. In order to determine the factors influencing values of EVA indicator in the agricultural enterprises the author have applied the correlation analysis, results of this analysis are presented in the Tab. I. Statistical significance of the value of Pearson correlation coefficient has been tested with the F-test on the significance level of $\alpha=0,05$. Results of the test are also presented in the Tab. I. ${ }^{2}$

I: Interaction between Values of EVA and chosen factors: pearson correlation coefficient with the test of statistical significance

\begin{tabular}{|c|c|c|c|c|c|c|}
\hline Factor & \multicolumn{2}{|c|}{ Region of Zlín } & \multicolumn{2}{|c|}{ South Moravia } & \multicolumn{2}{|c|}{ Whole } \\
\hline Equity & 0,2426 & $\mathrm{Y}$ & 0,3845 & $\mathrm{Y}$ & 0,3378 & $\mathrm{Y}$ \\
\hline Cost of Equity & $-0,1342$ & $\mathrm{~N}$ & $-0,2081$ & $\mathrm{Y}$ & $-0,1982$ & $\mathrm{Y}$ \\
\hline Cost of Debts & 0,1108 & $\mathrm{~N}$ & $-0,0256$ & $\mathrm{~N}$ & 0,0028 & $\mathrm{~N}$ \\
\hline Total Indebtedness & 0,1352 & $\mathrm{~N}$ & 0,1118 & $\mathrm{~N}$ & 0,1020 & $\mathrm{~N}$ \\
\hline Current Ratio & 0,0994 & $\mathrm{~N}$ & 0,0794 & $\mathrm{~N}$ & 0,0763 & $\mathrm{~N}$ \\
\hline $\mathrm{ROE}$ & 0,3984 & $\mathrm{Y}$ & 0,0728 & $\mathrm{~N}$ & 0,1140 & $\mathrm{~N}$ \\
\hline Risk Premium on Liquidity & $-0,3911$ & $\mathrm{Y}$ & $-0,2493$ & $\mathrm{Y}$ & $-0,2594$ & $\mathrm{Y}$ \\
\hline Risk Premium on Company's Size & $-0,4647$ & $\mathrm{Y}$ & $-0,4438$ & $\mathrm{Y}$ & $-0,4077$ & $\mathrm{Y}$ \\
\hline Risk Premium on Financial Stability & $-0,0292$ & $\mathrm{~N}$ & $-0,0108$ & $\mathrm{~N}$ & $-0,0061$ & $\mathrm{~N}$ \\
\hline Risk Premium on Financial Structure & 0,0108 & $\mathrm{~N}$ & 0,0417 & $\mathrm{~N}$ & 0,0294 & $\mathrm{~N}$ \\
\hline Scoring & $-0,1887$ & $\mathrm{Y}$ & $-0,0685$ & $\mathrm{~N}$ & $-0,1020$ & $\mathrm{~N}$ \\
\hline Index IN99 & 0,6695 & $\mathrm{Y}$ & 0,4755 & $\mathrm{Y}$ & 0,4860 & $\mathrm{Y}$ \\
\hline
\end{tabular}

Source: Authors' calculations

2 Results are marked as $\mathrm{Y}$ if the value of correlation coefficient is statistically significant or as $\mathrm{N}$ if it is statistically insignificant. 


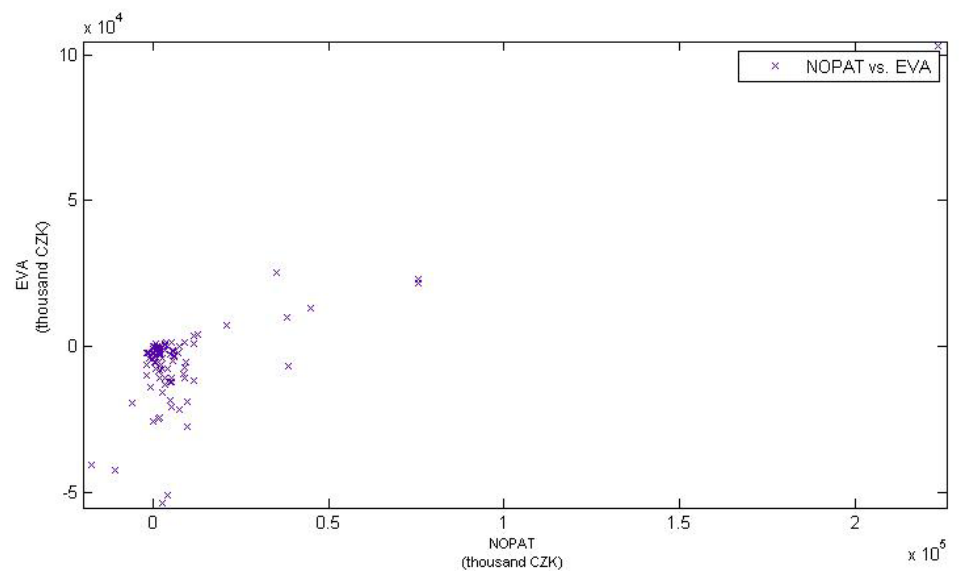

2: Graphical Analysis of interaction between EVA and NOPAT

Tab. I clearly shows that results of the economic value added have the strongest interaction with the net operating profit which is the basic variable entering its calculation. With regard to the values of correlation coefficient here, it is possible to assume a strong linear dependence between values of EVA and NOPAT which is statistically significant. Other variables entering the calculation of economic value added directly, i.e. equity, debts bearing interest, cost of equity and cost of debts, respectively weighted average cost of capital already don't have such a strong interaction.

Even if the Pearson correlation coefficient measuring the linear dependence between values of EVA and net operating profit is rather high, the graphical analysis (see Fig. 2) shows that another type of independence likely exists there, respectively at selecting the regression function another one should be preferred rather than the linear one.

From all the regression functions analysed, according to value of the determination the best results are obtained at application of the $4^{\text {th }}$ degree polynomial regression

$$
f(x)=p 1^{*} x^{\wedge} 4+p 2 * x \wedge 3+p 3 * x \wedge 2+p 4 * x+p 5,
$$
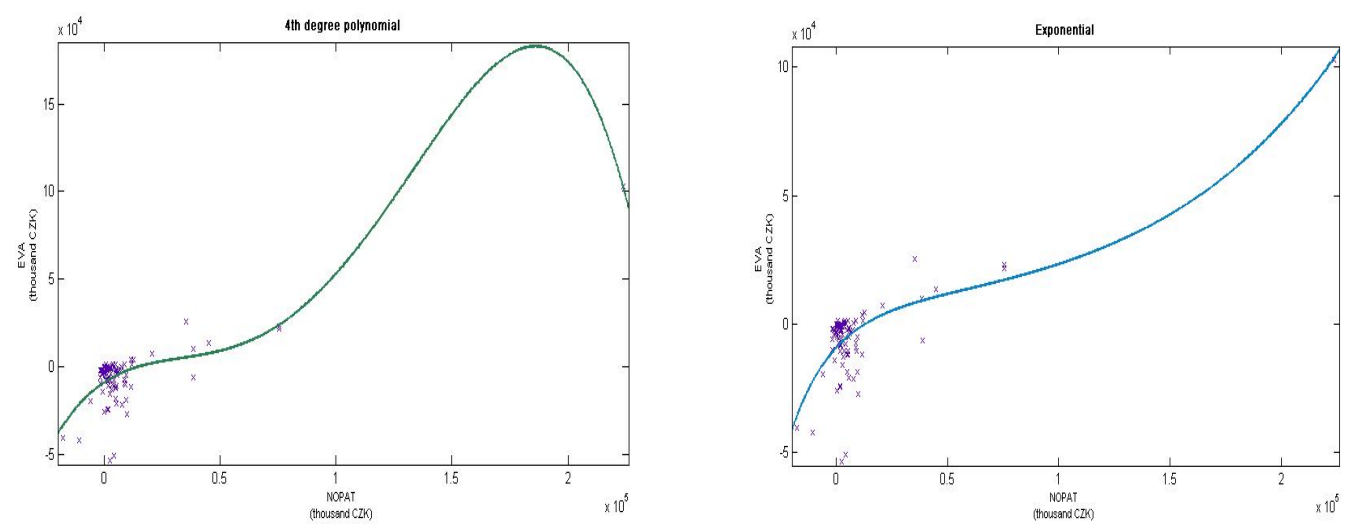

where:

$$
\begin{array}{lr}
\text { p1 }=-8.617 \mathrm{e}-016 & (-2.043 \mathrm{e}-015,3.198 \mathrm{e}-016) \\
\text { p2 }=2.866 \mathrm{e}-010 & (-7.322 \mathrm{e}-011,6.465 \mathrm{e}-010) \\
\text { p3 }=-2.274 \mathrm{e}-005 & (-4.64 \mathrm{e}-005,9.293 \mathrm{e}-007) \\
\text { p4 }=0.8907 & (0.4197,1.362) \\
\text { p5 }=-9200 & (-1.179 \mathrm{e}+004,-6608) .
\end{array}
$$

Values of the $p$-constants are completed with the confidence intervals on the significance level of 95 per cent. Value of the determination coefficient of

Another model which would be also suitable for modelling the interaction between values of EVA and NOPAT is exponential regression function

$$
f(x)=a^{*} \exp \left(b^{*} x\right)+c^{*} \exp \left(d^{*} x\right),
$$

where:

$\mathrm{a}=7758$

$\mathrm{b}=0.3136$

$(216.1,1.53 \mathrm{e}+004)$

$\mathrm{c}=-1.051 \mathrm{e}+004$

$\mathrm{d}=-1.376$

$(-2.241,-0.5116)$.

Also here the confidence intervals of the constants on the level of significance of 95 per cent are included while this model is characterized with the determination of 0.6010 . Both models are graphically presented on the Fig. 3. this model is 0.6023 .

3: Regression models of dependence between EVA and NOPAT 
Even if the value of coefficient of determination is slightly better for the $4^{\text {th }}$ degree polynomial regression model, from the logical point of view on the problem of the economic value added, more acceptable here is the second model, i.e. the exponential regression model. Here it is possible to suppose that in order to reach higher operating profit, it is necessary to increase the production capacity which is connected with higher need of capital, equity or debts. But both, equity and debts are bearing their costs decreasing the economic value added. That it is objectively possible to conclude that a growth economic value added connected with increases in operating profit is slowing from a certain point.

Another variable analyzed that creates the part of economic value added is the equity. Application of the Pearson correlation coefficient led to demonstration of medium weaker but statistically significant interaction (linear dependence) between values of EVA and equity. Graphical analysis presented on the Fig. 4 implies another type of dependence likely than the linear. From the graph it is rather visible that increases in values of equity lead to decreases in economic value added. This would support the presumption set in relation to the analysis of dependence of EVA on operating profit that higher amounts of capital lead to higher cost of equity which decreases the value of EVA.

The best results of the regression analysis between economic value added as depending variable and equity as independent variable have been obtained at application of the $5^{\text {th }}$ degree polynomial regression function

$$
f(x)=p 1^{*} x^{\wedge} 5+p 2^{*} x^{\wedge} 4+p 3^{*} x^{\wedge} 3+p 4^{*} x^{\wedge} 2+p 5^{*} x+p 6,
$$

where:

$\mathrm{pl}=2.06 \mathrm{e}-023$

p2 $=-3.286 \mathrm{e}-017$

p3 $=1.673 \mathrm{e}-011$

p4 $=-2.596 \mathrm{e}-006$

p $5=-0.01444$

$\mathrm{p} 6=-427.6$
Coefficient of determination of this model has the value of 0,6155 . Coefficients $p$ are again supplemented with the confidence intervals on the significance level of 95 per cent.

Prediction ability around 60 per cent is characteristic also for the quadratic polynomial regression model

$$
f(x)=p 1^{*} x^{\wedge} 2+p 2 * x+p 3
$$

where:

$\mathrm{pl}=3.814 \mathrm{e}-007$

(3.083e-007, 4.546e-007)

p2 $=-0.1544$

$(-0.1982,-0.1107)$

p3 $=104.3$

The confidence intervals on the significance level of 95 per cent are added to the values of constants $p$. This regression model has the prediction ability of 59.11 per cent, respectively the determination coefficient has the value of 0.5911 . These two models are graphically compared on the Fig. 5.

The $5^{\text {th }}$ degree polynomial regression model could be a good variant of expression of the dependence of the economic value added on the values of equity. It comes out from the viewpoint of increasing the production capacity. As it was mentioned above, higher production capacity expects an increase in capital need of a company. Such an increase implies increase in the cost of capital. Then it is possible to assume that a leap increase in equity would lead to decrease in economic value added. At gradual making this new production capacity full, the operating profit is likely increasing, and the economic value added is increasing as well until a point of full production capacity where it has to be extended again, i.e. to increase the capital employed. Here it is also possible to set the premise that equity has stronger impact on the economic value added than debts because of the difference in cost of these two types of capital.

Approximately same linear dependence measured with the Pearson correlation coefficient as was observed between the values of EVA and equity exist also between the values of EVA and debts bearing interest. Consequently, it is medium weaker direct

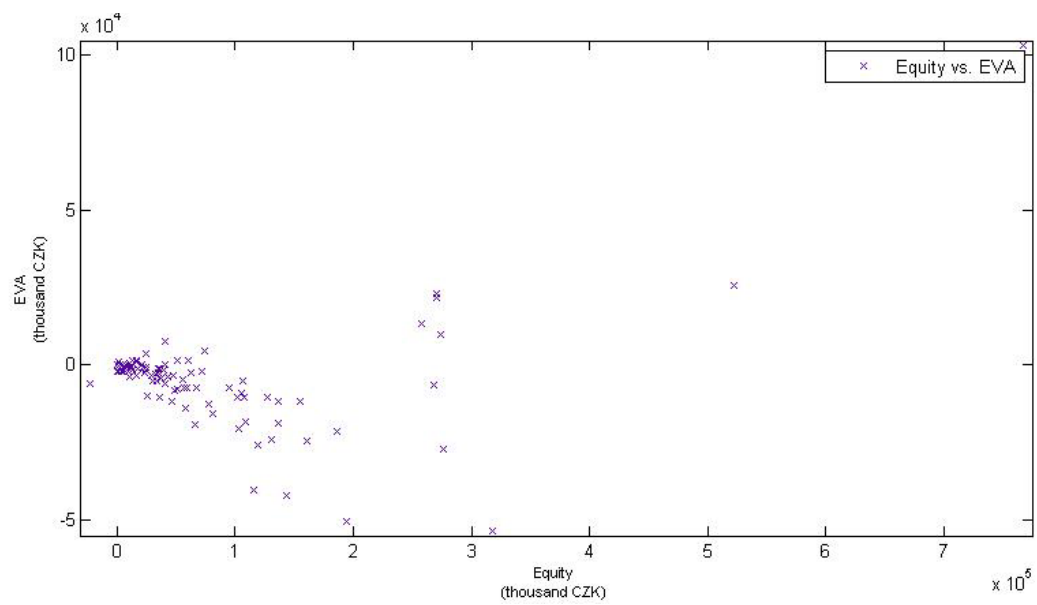

4: Graphical analysis of interaction between EVA and equity 

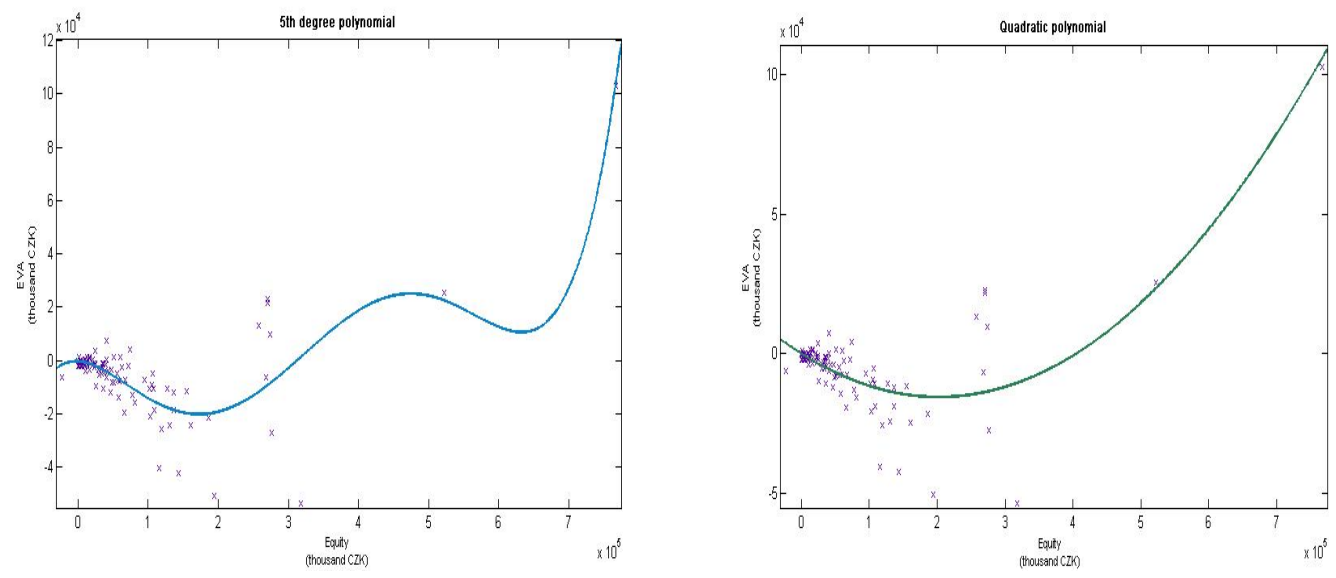

5: Regression Models of Dependence between EVA and Equity

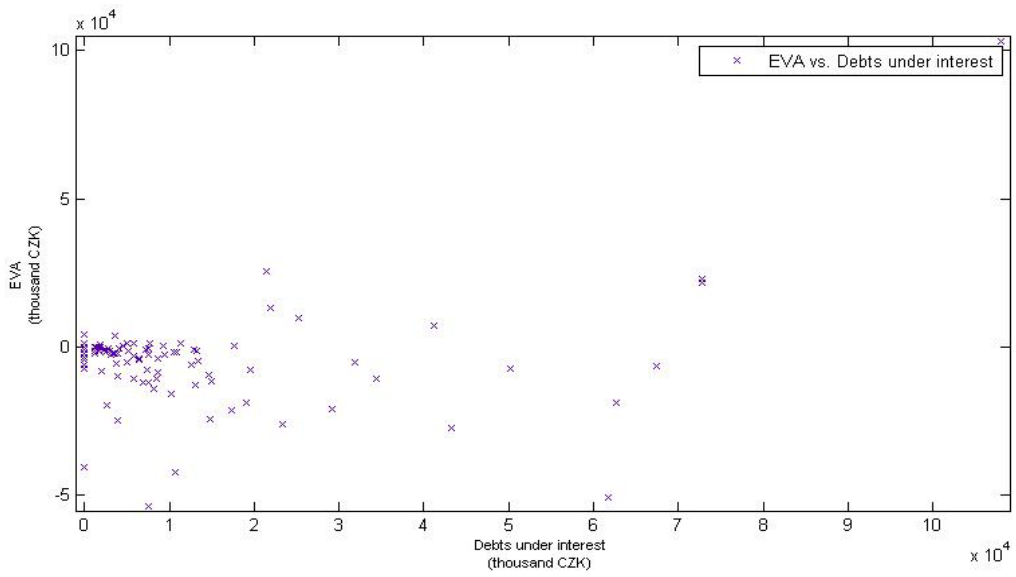

6: Graphical analysis of interaction between EVA and Debts Bearing Interest

linear dependence which is statistically significant in the statistical set of all the units. On the other side, this dependence is minimal, on the level of 10.24 per cent only and statistically insignificant in the set of the agricultural companies from the Region of Zlín. With the perspective on the data point presented on the Fig. 6 it is visible that it would be rather difficult to find a good type of functional dependence with good prediction ability.

Prediction ability of any regression model tested has not exceeded 50 per cent. With the determination coefficient of the value of 0.4782 , the best prediction ability has the exponential regression model

$$
f(x)=a^{*} \exp \left(b^{*} x\right)+c^{*} \exp \left(d^{*} x\right)
$$

where:

$\mathrm{a}=1.003 \mathrm{e}+006$

$\mathrm{b}=3.437 \mathrm{e}-005$

$\mathrm{c}=-1.008 \mathrm{e}+006$

$\mathrm{d}=3.43 \mathrm{e}-005$

$(-1.064 \mathrm{e}+012,1.064 \mathrm{e}+012)$

$(-0.03849,0.03856)$

$(-1.064 \mathrm{e}+012,1.064 \mathrm{e}+012)$

$(-0.03845,0.03852)$

At single constants, the confidence intervals of their values on the significance level of 95 per cent are presented as well.
Prediction ability over 40 per cent has been observed for the quadratic polynomial regression model

$$
f(x)=p 1^{*} x^{\wedge} 2+p 2 * x+p 3
$$

where:

$\mathrm{pl}=1.646 \mathrm{e}-005$

$(1.19 \mathrm{e}-005,2.102 \mathrm{e}-005)$

$\mathrm{p} 2=-0.9782$

$(-1.353,-0.6032)$

p3 $=-849.4$ $(-4657,2958)$.

Determination coefficient of this model has the value of 0,4254. Graphs of both models are presented bellow on the Fig. 7.

With regard to the determined influences of equity and debts on the values of EVA, subsequently the influences of these variables on weighted average cost of capital have been analyzed as well. Due to the different sizes of agricultural enterprises in the statistical set, it is irrelevant to analyze the absolute values of these variables. For this reason the variables have been transformed into their shares on the total capital of a company, i.e. new variables of share of equity and share of debts bearing interest on the capital structure have been used. This dependence is medium weaker again. 

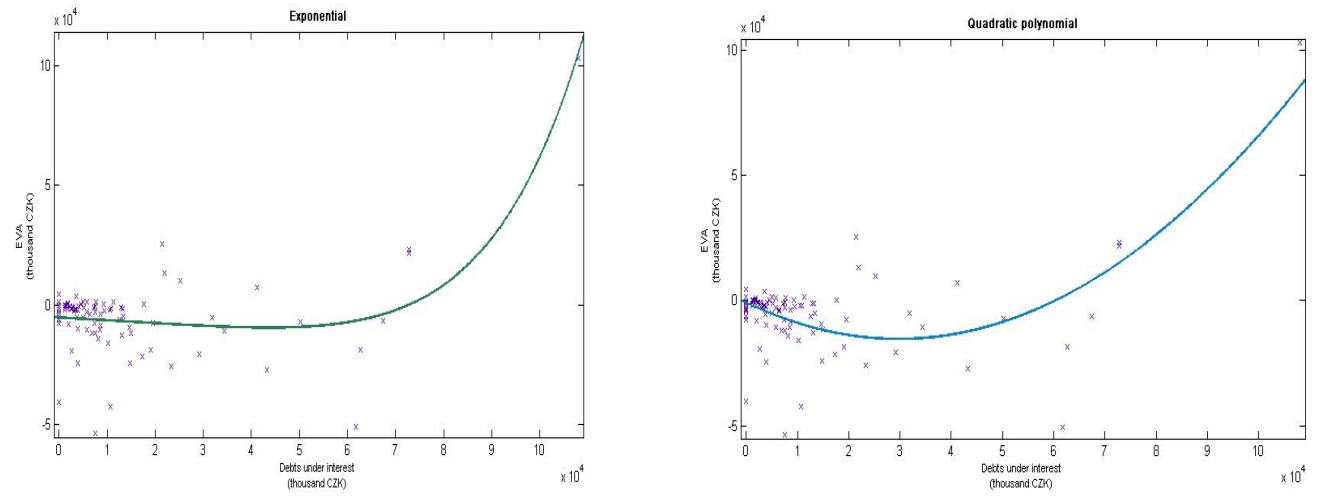

7: Regression models of dependence between EVA and Debts Bearing Interest

The absolute value of the Pearson correlation coefficient is 0.3505 while this dependence has been proved as statistically significant. As of the single dependences, there is the indirect dependence between WACC and share of debts on capital structure, and direct dependence between WACC and the share of equity on capital structure. It means that higher employment of equity in the capital structure increases the average cost of capital and in the opposite employment of debts makes the cost of capital lower. This conclusion corresponds with theory of the U-shape curve of the weighted average cost of capital. Even if the dependence between these WACC and these variables has been proved by the F-test on the significance level of $\alpha=0.05$ as statistically significant, the outcomes of regression analyses are not quite satisfactory. Prediction ability of the models is very low, the best regression model tested was the cubic polynomial function which had the determination coefficient value only on the level of 0.2272. This result is of course the same for both, for the regression between WACC and the share of equity on capital structure as well as for the regression between WACC and the share of debts on capital structure. The only difference is that for the share of equity the regression function is increasing, and on the opposite for the share of debts the regression function is decreasing.

Variables share of equity and share of debts on capital structure have only very low influence on the values of EVA. Interaction between EVA and these variables is expressed by the Pearson correlation coefficient of the absolute value of 0.1145 while this value is positive for interaction with debts share and negative for interaction with share of equity.

Other factors which are necessarily under consideration at determining the influences on economic value added are the costs related to the capital employed, i.e. cost of equity, cost of debts, and also their aggregate form - weighted average cost of capital. Influence of the partial variables, i.e. of separate cost of equity and separate cost of debts is insignificant. Pearson correlation coefficient for the dependence between economic value added and the cost of equity has the value of -0.1982 and its value for the dependence between EVA and cost of debts is almost null ( $r=0.0028)$. Because of these results, it is not reasonable to follow with the analyses of these two separate variables. Their aggregation completed with the share of equity and share of debts on capital structure are components of the weighted average cost of capital. Pearson correlation coefficient measuring the linear dependence between WACC and the cost of equity has the value of 0.3945 and for the linear dependence between WACC and cost of debts the value is 0.2495 . These interactions both have been tested for statistical significance and by the F-test they have been proved as statistically significant. As of the interaction between economic value added and weighted average cost of capital, Pearson correlation coefficient with its value of -0.3762 refers to the medium weaker indirect linear dependence. Distribution of the data points is presented on the Fig. 8.

All the regression models tested have been characterized by very low prediction ability which mostly did not exceed 20 per cent. The only exception is the $9^{\text {th }}$ degree polynomial regression model, but its application has no logical reasons. As relatively suitable, especially for its shape, could be regarded the cubic polynomial function

$$
f(x)=p 1^{*} x^{\wedge} 3+p 2^{*} x^{\wedge} 2+p 3^{*} x+p 4,
$$

where:

$\mathrm{pl}=1.443 \mathrm{e}+007$

$\mathrm{p} 2=-5.882 \mathrm{e}+006$

$\mathrm{p} 3=5.014 \mathrm{e}+005$

$(5.386 \mathrm{e}+006,2.347 \mathrm{e}+007)$

p4 $=1344$

$(-9.805 \mathrm{e}+006,-1.959 \mathrm{e}+006)$

$(-2.622 \mathrm{e}+004,1.029 \mathrm{e}+006)$

$(-2.378 \mathrm{e}+004,2.647 \mathrm{e}+004)$.

The p-constants are presented with their confidence intervals on the 95 per cent significance level while the determination coefficient of this model has the value of 0.2290 .

From the fundamentals of relation between economic value added and weighted average cost of capital, it is also possible to consider a decreasing exponential function which seems to be more correct when reflecting the logic of this interconnection. Exponential regression model has been constructed in the form as follows 


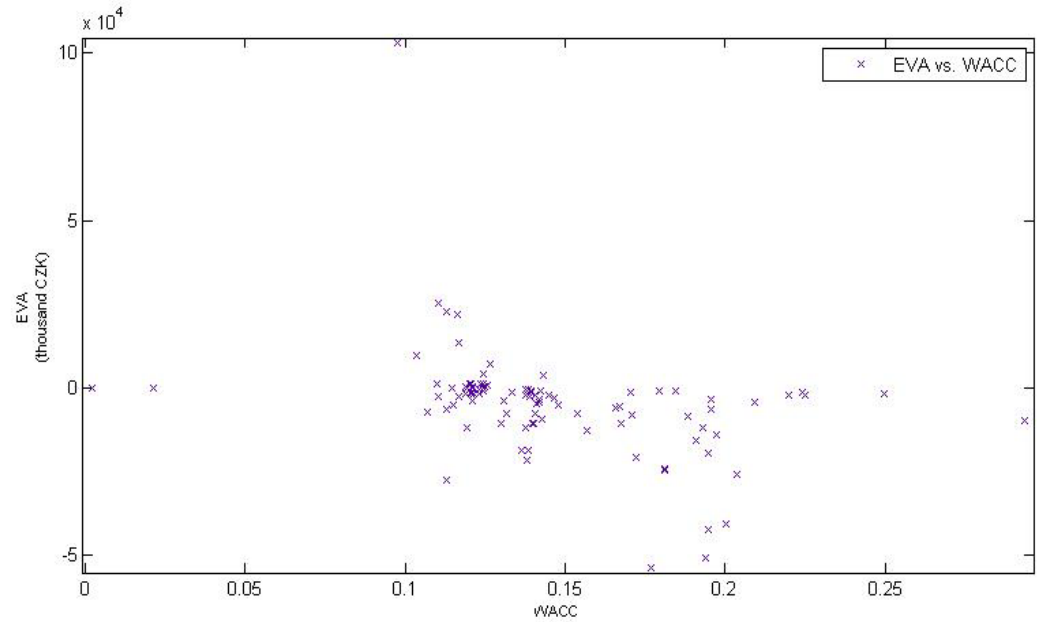

8: Graphical analysis of interaction between EVA and WACC

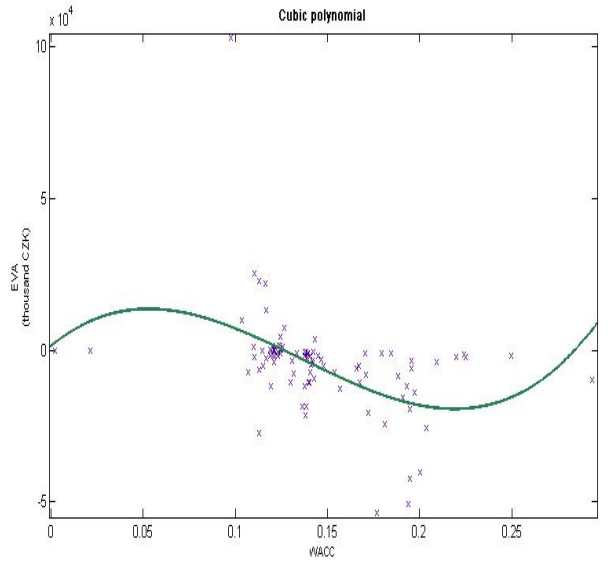

9: Regression models of dependence between EVA and WACC

$$
f(x)=a^{*} \exp \left(b^{*} x\right)+c^{*} \exp \left(d^{*} x\right)
$$

where:

$\mathrm{a}=-8.869 \mathrm{e}+009$

$\mathrm{b}=-0.7958$

$\mathrm{c}=8.869 \mathrm{e}+009$

$\mathrm{d}=-0.7959$

$(-8.818 \mathrm{e}+018,8.818 \mathrm{e}+018)$ $(-9980,9978)$

$(-8.818 \mathrm{e}+018,8.818 \mathrm{e}+018)$ $(-9980,9978)$,

but the prediction ability of this model given by the determination coefficient is only on the level of 0.1428. Eventually considered linear model has approximately the same value of determination, i.e. 0.1415. Comparison of cubic polynomial and exponential model is presented on the Fig. 9.

All the essential variables entering to the calculation of economic value added have been subsequently aggregated into one multidimensional linear regression model where the EVA is defined as depending variable and independent variables are net operating profit after taxation, equity, debts bearing interest, and weighted average cost of capital. The result of multi-dimensional linear regression is the function

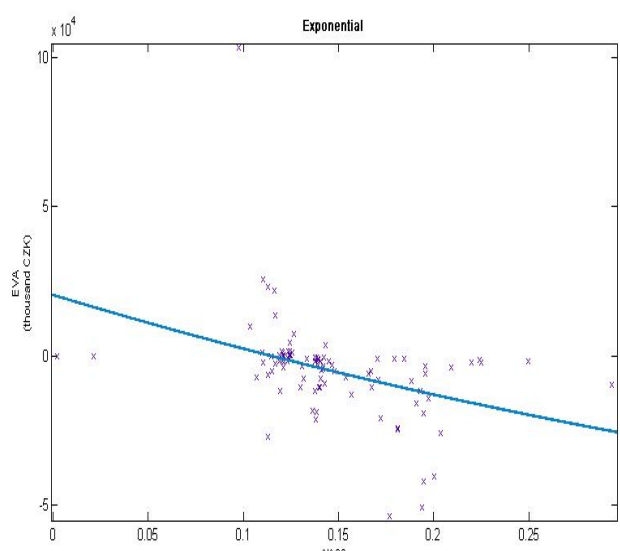

$$
y=0,9438 x_{1}-0,0812 x_{2}-0,3200 x_{3}-18086 x_{4},
$$

where:

$\mathrm{y}$.... is economic value added

$\mathrm{x}_{1} \ldots$ is net operating profit after taxation (NOPAT)

$\mathrm{x}_{2} \ldots$ is equity

$\mathrm{x}_{3} \ldots$ are debts bearing interest

$\mathrm{x}_{4} \ldots$ are weighted average cost of capital (WACC).

Determination coefficient of this model has the value of 0.8432 . This value expresses that this multidimensional linear regression model has relatively good prediction ability. The relevance of this model has been tested with the F-statistics that verifies if the dependent variable, i.e. the economic values added is a linear combination of selected functions of independent variables.

The null hypothesis of this test of the model relevance expresses the premise that the regression model is not statistically verified. Then, this null hypothesis is rejected, and the alternative hypothesis is accepted when $F>F_{\text {crit }}$. The critical value is quantile of Fisher distribution on defined level of significance which has been set on $\alpha=0.05$ for this test. Results of the applied F-test rejected the 
null hypothesis. It means that with the probability of 95 per cent the regression model is statistically significant.

Plus and minus signs of the regression coefficients shows the essential of the basic calculation of economic value added which is derived from the operating profit that is decreased by the cost of capital. But all the regressors separately are the functions of other variables; in this paper, for example the components of weighted average cost of capital are analysed. From construction of the multidimensional regression model, it is also visible that regression coefficient $b_{0}$ is of the zero value. This corresponds with the logic of the company's financial performance because it is supposed that if the zero operating profit, zero equity, zero debts and subsequent zero cost of capital a business entity does not exist in fact. This way, its financial performance has to be zero.

\section{DISCUSSION AND CONCLUSION}

Net operating profit after taxation, equity and debts, and weighted average cost of capital are the variables directly entering the calculation of economic value added. Behind these variables stand a number of partial variables, as it is visible from the EVA decomposition presented on Fig. 1. These partial factors are influencing, more or less, the final value of EVA indicator measuring the financial performance of a business entity. It is also interesting, and more over, from the statistical point of view it is necessary to observe mutual interactions between these partial components. The strength of influence of these factors on the values of EVA has been measured with the Pearson correlation coefficient, and it has been unequivocally proved that the strongest is the influence of the net operating profit.

But in the agricultural enterprises, the substantial part of this net operating profit consists in the revenues from subsidies. After elimination of these subsidies, agricultural business activities become strongly unprofitable. The agricultural productions subsidies are then spoken not only as an important financial resource of agricultural enterprises, but these subsidies are also spoken as a significant source of operational risk. But in this context, the agricultural productions subsidies are also the very important source of financial performance of business entities operating in this sector.

\section{SUMMARY}

Performance of business entities is regarded from various points of view. It is also often connected with a productivity which is determined by percentage of a resource utilization and production speed of a resource. In this context, the agricultural enterprises are quite specific because of their inability to influence these two determinants effectively, especially the production speed of their resources. Objective of this paper is to identify the key influences on financial performance of agricultural enterprises measured with the indicator of Economic Value Added. The agricultural enterprises are characteristic with very low financial performance which is currently spoken in relation to the agricultural subsidies government policy. The paper is based especially on the quantitative primary research. In order to fulfil the aim of the paper, two statistical sets of agricultural enterprises have been analyzed, one consisting of 50 agricultural enterprises from the Region of Zlín, and the second consisting of 50 agricultural enterprises from the South Moravian Region. On these statistical units 13 characteristics entering, directly and indirectly, the calculation of economic value added. Subsequently, thy analyses of interaction between variables have been applied, especially correlation and regression analyses, and the analysis of variance.

Results of the correlation analysis show that the most significant influence on the economic value added comes from the side of net operating profit where strong linear correlation has been observed. But outcome of the regression analysis leads to conclusion that exponential expression of dependence of economic value added on net operating profit is more suitable than a linear model. In the same way also equity, debts bearing interest, and weighted average cost of capital have been analysed. All the analyses and their results prove the premise concerning to a production capacity. On the provided graphs, it is quite well visible that higher production capacity lead to higher capital need of a business entity. But leap increase in capital lead to decrease in economic value added because of increasing cost of capital while equity has stronger influence than debts due to the fact that equity is more expensive than debts. But if a company should make its profits higher, extension of production capacity is necessary, especially because of improbable positive changes in the prices of agricultural commodities. Aggregation of these premises concludes that the growth of EVA would always be slower than the growth of operating profit, and this is also visible on the graph of regression between EVA and NOPAT. 
All the four independent variables are finally comprised in multi-dimensional regression model. At application of the F-test, constructed model has been proved as statistically significant. Regression coefficients of the model correspond with essentials of basic calculation of the economic value added. Nevertheless, even if the operating profit has been defined as the strongest influence on economic value added a substantial part of this profit consists in the revenues from agricultural productions subsidies. After their elimination, agricultural enterprises would be in deep losses. This way, agricultural productions subsidies become the very important source of financial performance of agricultural enterprises.

\section{REFERENCES}

BERANOVÁ, M., BASOVNÍKOVÁ, M., MARTINOVIČOVÁ, D., 2010: Problematické aspekty ekonomické přidané hodnoty v podmínkách ČR. Acta universitatis agriculturae et silviculturae Mendelianae Brunensis, LVII, No. 6. (v tisku).

HAMILTON, J., RAHMAN, S., LEE, A. C., 2009: EVA: Does Size Matter? Review of Pacific Basin Financial Markets and Policies, Vol. 12, No. 2, 267-287.

KISLINGEROVÁ, E., 2009: Jak měřit výkonnost podniku v časech krize. ÚSPĚCH - produktivita \& inovace v souvislostech, Vol. 4, pp. 12-15. ISSN 1803-5183.
NEUMAIEROVÁ, I., NEUMAIER, I., 2002: Výkonnost a tržníhodnota firmy. 1. vyd. Praha: Grada Publishing. ISBN 80-247-0125-1.

REMEŠ, D., 2009: Řízení výkonnosti podniku v době krize. Journal of Competitiveness, Vol. 1, pp. 56-65, December 2009. ISSN 1804-1728.

SEJÁK, J. et al., 2011: Globalizace a udržitelnost českého zemědělství (Globalization and Sustainability of the Czech Agriculture). On-line available from: http://fzp.ujep.cz/projekty/lJ055-05-DP1/Glob_URCSZ07_EK_AK1.ppt.

SKORKOVSKÝ, J., 2005: Produktivita výroby a výkonnost podniku. Automa, Vol. 10, pp. 6-8. ISSN 1210-9592.

STEWART, G. B., 1991: The Guest for Value. New York: HarperCollins Publishers.

Ing. Michaela Beranová, Ph.D., Ing. Bc. Marcela Basovníková, Ústav podnikové ekonomiky, Mendelova univerzita v Brně, Zemědělská 1, 61300 Brno, Česká republika, e-mail: michaela.beranova@mendelu.cz, marcela.basovnikova@mendelu.cz 
